\title{
The Efficacy Beliefs of Turkish Social Studies Teacher Candidates Regarding the Teaching-Learning Process ${ }^{*}$
}

\author{
Ali Altıkulaç \\ Çukurova University, Adana, Turkey
}

\author{
Salih Uslu \\ Niğde University, Niğde, Turkey
}

\begin{abstract}
The aim of this study was to examine the efficacy beliefs of social studies teacher candidates (SSTCs) related to the teaching-learning process. This study focused on the areas of sub-competences of social studies education; and examined whether these competence levels were changed in terms of variables of gender and type of education and what were the expectations of them. The study group was 360 SSTCs continuing education in their final year selected from five universities. To analyze the gathered data, descriptive statistics, correlations, and $t$-tests were performed. Besides, content analysis was made to analyze the qualitative data. The findings indicated that there was a highly significant positive relation among the areas of sub-competences. Female SSTCs and SSTCs in evening education had significantly higher efficacy beliefs regarding the teaching-learning process. It was also found that SSTCs wanted some modifications towards the teacher training program they received.
\end{abstract}

Keywords: pre-service social studies teachers, efficacy belief, teaching-learning process

\section{Introduction}

It is of great importance that teacher training programs' content, scope, and objectives will reach the teacher candidates studying at the faculties of education; it is also important that teacher candidates' beliefs related to reach the undergraduate program goals. The teaching profession by its very nature is based on spiritual factors, so students who are trained in education faculties must believe that they can do this profession. No matter how rich or heavy theoretical or practical knowledge is provided during the undergraduate education, it can be only observed in the process of performing their profession. There are many factors that can affect teachers' learning and teaching skills in the educational process. One of them is the beliefs intended for competences that they should have.

The concept of self-efficacy, developed by Albert Bandura, is one of the most basic concepts of Social Learning Theory, which was changed into Social Cognitive Theory in 1986. According to this theory, almost every decision is primarily shaped in thought. People's efficacy beliefs affect the types of their scenarios that they configure and rehearse for the future. People who have a sense of high self-efficacy imagine the successful scenarios that provide positive guidance and performance supporting; those have a doubt about their efficacy imagine failure scenarios and obsess many things that may go wrong. It is difficult to achieve success while struggling with the continuous self-doubt (Bandura, 1993).

* This article was presented at The Third Asian Conference on Society, Education \& Technology held in Kobe, Japan, October 21-25, 2015.

Ali Altıkulaç, Ph.D., research assistant, Department of Elementary Education, Faculty of Education, Cukurova University.

Salih Uslu, Ph.D., assistant professor, Department of Elementary Education, Niğde University. 
Bandura (1995) revealed self-efficacy which distinguishes people on matters of thinking, feeling, acting, and self-motivating, which are the beliefs about what the individuals can do related to a particular field. A low sense of self-efficacy is associated with stress, depression, helplessness, and anxiety. Such individuals have low self-perception, and pessimistic about their success and personal development. A strong sense of efficacy facilitates the cognitive processes and performance in the various frames including effective decision-making and academic achievement. Self-efficacy can affect people's preferences for action. The levels of self-efficacy can enhance or undermine motivation. People with high self-efficacy undertake an enterprise and do not avoid to resolve the similar problems and challenges. Individuals' self-efficacy beliefs are to determine the levels of motivation about how they would persevere to face with difficulties. The triumphs obtained in the face of difficulties indoctrinate a stronger belief to the person about ability to face difficulties. Bandura explains self-efficacy as beliefs which act as an important sequence of human motivation determinants. These beliefs create a form of an action as a means of motivational, cognitive, and emotional processes (Bandura, 1989b). A higher level of perceived self-efficacy leads to a higher level of targets that people set for themselves and to be affiliated with these goals at a higher level (Zulkosky, 2009).

The self-efficacy of teacher or trainer refers to individual beliefs about their ability to help students learn. A teacher's efficacy belief is a judgment towards oneself related to transport abilities to the desired goals even if there are reluctant students or students with learning disabilities (Tschannen-Moran \& Hoy, 2001). The beliefs about self-efficacy regarding encouraging and developing the instruction by teachers affect the level of academic process intended for student achievement and learning environment that they created (Bandura, 1993). Social cognitive theory predicts that teachers' self-efficacy beliefs affect students' self-efficacy, action choices, perseverance, effort, and success in the same way. Teachers with high self-efficacy beliefs develop inquiry activities, help to provide students success, and are insistent on students with learning difficulties (Schunk \& Pajares, 2009, p. 38). In addition, teachers' efficacy beliefs are also closely related to their behaviors in the classroom. Efficacy influences their efforts to develop education, trying to reach the goals and the levels of passion. Teachers who have a strong sense of efficacy tend to exhibit a higher level of organizing and planning. Furthermore, they are more open to new ideas and more willing to try new methods to meet students' needs better. Efficacy beliefs affect teachers' resistance to confront setbacks and their persistence for solution-oriented if things do not go right. High efficacy level enables teachers to be less critical when their students make mistakes, to work more with challenging students, and to be less prone to direct the students with learning difficulties to special education (Tschannen-Moran \& Hoy, 2001).

Hoy (2000) revealed that expertise experiences gained through years of training and education were at the top of the most powerful effects in the development of teaching efficacy. Therefore, the first years of teaching play a critical role on long-term development of teaching efficacy. Hoy (2000), based on the work of Bandura, explained other factors that would affect teachers' sense of efficacy in two groups:

(a) Vicarious experiences (One teacher may observe effective practices of another teacher, thus, this teacher feels more aware of himself/herself and can be more successful to reach students applying these);

(b) Social persuasion (In the school environment, it can be a form of feedback emphasizing the effective educational behaviors or supporting speeches).

Numerous studies indicate that there is a close relationship between student achievement and teachers' knowledge, skills, and practices (Guyton \& Farokhi, 1987; Hawk, Coble, \& Swanson, 1985). Therefore, what teachers know and perform is of great importance on what students can learn (Darling-Hammond, 2002). Ross 
(1992) examined the effect of teachers' efficacy on student achievement (cognitive and academic skills) in his research with a group of 7th and 8th grade history teachers. In the implementation process, it was observed that student achievement was higher in classes whose teachers were more in contact with counselors who worked to develop teachers' efficacy and in which the students were more willing to participate in the teaching event.

Increase of teachers' self-efficacy who are in their early years in the profession is critically important for student success in schools, which especially need qualified, competent, and confident educators (Elliott, Isaacs, \& Chugani, 2010). As stated by Goddard, Hoy, and Hoy (2000), "To train the most brilliant teachers is not enough, it is also required that the teachers should believe who successfully handle difficulties which may arise when pursuing their duties." Teacher candidates, who graduated with a low sense of efficacy, tend to be redirected; they have a pessimistic perspective towards student motivation, and they use the temporary rewards and punishments to make students study based on the solid-class regulations. Once engaged in the education of students, efficacy beliefs have effect on behavior as well. Teacher candidates with high individual teaching efficacy are evaluated in a more positive way by the internship teacher on issues of lecturing, classroom management, and behavioral inquiry (Saklofske, Michaluk, \& Randhawa, 1988).

In the teaching process, the majority success or failure of teachers is based on their ability of instant decision-making with respect to the impact on students and managing classes. In order to be successful, teachers should feel confident in point of capabilities, such as reading and interpreting verbal or non-verbal communication of students, recognizing, reflecting, and handling their own feelings, also helping students overcome emotions and their experiences of classroom learning (Hoy, Hoy, \& Davis, 2009).

Social studies teachers, who work in the second stage of primary education, try to let the students gain various features through scientific knowledge and skills acquired and the education they received. In order to make the students gain specified knowledge, skills, and values, it is required that social studies teachers are equipped with the necessary knowledge and skills about the quality and features of this field during their training in faculties of education. In this context, teacher candidates studying in the Department of Social Studies Education take courses such as history, geography, psychology, philosophy, sociology, and educational sciences (Demircioğlu, 2006). However, as a result of the four-year undergraduate education, do teacher candidates think to have qualifications required for the teaching profession? To use teaching skills more effectively, teachers need to have self-reliance, in other words, they should have strong efficacy beliefs. Efficacy beliefs in a specific area of social studies teachers may not affect the other areas, those efficacy areas are: organization and planning of the teaching process, teaching-learning process, monitoring and evaluation, collaboration on school-family and community, and providing professional development. The teaching-learning process area may be the most important of these areas, because it is directly related to students. In this respect, this study was conducted for the purpose of putting forth about how they see themselves in the teaching-learning process related to the vocational fields of the teacher candidates studying social studies education section.

\section{Sub-competences Related to Efficacy Area of the Teaching-Learning Process}

Sub-competences related to the teaching-learning process determined based on social studies teachers' specialized field competencies prepared by Turkish Ministry of Education. In order to fulfill teachers' duties effectively, these competences include the field information and skills of organizing, teaching, and educating.

Sub-competence 1: To make students gain the consciousness of the protection and promotion of cultural heritage and basic elements and processes that constitute Turkish history and culture. 
Sub-competence 2: To help students perceive the interaction of human, earth, and environment.

Sub-competence 3: To get students comprehend the impact of economic activities and developments on societies.

Sub-competence 4: To make students gain the consciousness of understanding the democratic governance, and the people have responsibilities towards people, society, and humanity because of their innate and acquired rights.

Sub-competence 5: To get students comprehend the importance of the basic principles that are based on Atatürk's principles and reforms and the meaning of the Turkish revolution, and its effects on the society's political, social, cultural, and economic areas developments.

Sub-competence 6: To be able to make practices which take students who need special education and special needs into account.

\section{Aim of the Study}

This study aims to evaluate social studies teacher candidates' (SSTCs) efficacy beliefs in relation to the teaching-learning process according to areas of sub-competences. The study addresses the following research questions:

1. How are the efficacy beliefs of SSTCs related to the teaching-learning process according to gender and education type variables?

2. How are the expectations of SSTCs about the learning-teaching process towards the teacher training program at the undergraduate level?

\section{Method}

\section{Research Model}

This study was carried out using the causal comparative research method. Because of the descriptive method generally used in educational research in order to learn about attitudes, beliefs, and views of the selected group about a specific topic (McMillan \& Schumacher, 2006) in this study, descriptive (survey) method was used as the basic research design. This study examined the beliefs levels and relationships between variables of gender, education type, and correlations of sub-competences.

\section{Participants}

The number of ongoing students was 21,849 in the Department of Social Studies Education during the academic year of 2012-2013 in Turkey. The sample was selected by purpose sampling. Universities that represent different regions of the country were selected. During the 2012-2013 academic year, of all the 360 participants, $159(44.2 \%)$ were female and $201(55.8 \%)$ were male final year students in social studies education departments at the faculties of education of the selected five universities (Çukurova University, Gazi University, Akdeniz University, Muğla Sttkı Koçman University, and Niğde University) located in the central and southern parts of Turkey. According to education type, of the entire participants, 199 (55.3\%) were in daytime education and $161(44.7 \%)$ were in evening education.

\section{Instruments}

The Inventory of Social Studies Teacher Candidates' Efficacy Beliefs Regarding Teaching-Learning Process (ISSTCEBRTLP) - developed by researchers - was designed to determine the SSTCs' beliefs in accordance with competencies that are revealed by Turkish Ministry of National Education. The inventory 
consists of six sub-areas, each of which has its own factors. These areas are described above (For example, sample item for sub-competence area 1: "I can make students realize the change and continuity of basic elements of Turkish history and culture"; sample item for sub-competence area 2: "I can make students gain the skill of spatial perception"; sample item for sub-competence area 3: "I can make them to recognize the structure, features of the economy and the factors affecting the economy"; sample item for sub-competence area 4: "I can make them to comprehend the basic principles of democracy and democratic governance approach"; sample item for sub-competence area 5: "I can make them to comprehend the basic principles based on Atatürk's principles by presenting the examples"; and sample item for sub-competence area 6: "I can do the planning to ensure social development of students who need special education and special needs."). The inventory consists of 46 items and 1-5 Likert rating scale. High marks taken from each sub-competence area indicate the presence of those candidates' beliefs. In addition, there is a chapter attempting to measure candidates' desires towards their probable deficiencies in the last part of the scale (For example, an open-ended item for qualitative data: "At the undergraduate level, to which subject or courses do you want to be given weight to find solutions for some deficiencies that you stated in items.").

In the process of test construction, factors of test were generated based on experts' opinion and it was made foreground application. For the validity, factor analysis was administered. Kaiser-Meyer-Olkin measure of sampling adequacy was found to be 0.92 for the ISSTCEBRTLP. The factor loads of the inventory changed from 0.44 to 0.72 . As for the reliability, Cronbach's alpha reliability coefficient was found to be 0.94 for the ISSTCEBRTLP.

\section{Data Analysis}

Quantitative and qualitative analyses were used for the analysis of the results. Descriptive statistics and comparison analysis were used for quantitative data analysis. The results were analyzed using the Statistical Package for Social Sciences (SPSS) 20.00. Quantitative data were analyzed using the independent sample $t$-test, Pearson correlation coefficients, and descriptive statistics. Qualitative data were analyzed using the content analysis. Data obtained from two data sets were analyzed in comparison.

\section{Results}

\section{How Are the Efficacy Beliefs of SSTCs Related to the Teaching-Learning Process According to Other Variables?}

Means and standard deviations are given as well as the correlation coefficients among areas of sub-competences for the teaching-learning process in Table 1. As seen in Table 1, there are good levels of beliefs in each area and positive correlations among all sub-competences. Looking at means, it was observed that positive beliefs at the highest level were in the fourth sub-competence area while the lowest level in the sixth sub-competence area. Looking at items one by one, the candidates felt themselves most competent about this item: "I should be careful to be democratic and tolerant about my daily communications and teaching process" $(M=4.48)$ and the most incompetent items: "I can cooperate with relevant institutions and organizations by preparing projects in order to identification of fundamental rights and responsibilities" ( $M=3.63)$, "I can guide my colleagues in the preparation of projects introducing and adopting democracy" $(M=3.64)$, and "I can make students create ideas for the future and to produce solutions in cooperation with institutions and organizations towards problems encountered in interaction of human, place, and environment" $(M=3.69)$. 
Table 1

Descriptive Statistics and Correlations of the Sub-competences Regarding the Teaching-Learning Process

\begin{tabular}{lllllllll}
\hline Sub-competence & 1 & 2 & 3 & 4 & 5 & 6 & $M$ & $S D$ \\
\hline 1 & - & - & - & - & - & - & 3.96 & 0.84 \\
2 & $0.688^{*}$ & - & - & - & - & - & 4.03 & 0.79 \\
3 & $0.550^{*}$ & $0.652^{*}$ & - & - & - & - & 4.00 & 0.82 \\
4 & $0.612^{*}$ & $0.732^{*}$ & $0.637^{*}$ & - & - & - & 4.10 & 0.78 \\
5 & $0.544^{*}$ & $0.529^{*}$ & $0.441^{*}$ & $0.589^{*}$ & - & - & 4.08 & 0.88 \\
6 & $0.364^{*}$ & $0.457^{*}$ & $0.429^{*}$ & $0.543^{*}$ & $0.360^{*}$ & - & 3.89 & 0.95 \\
\hline
\end{tabular}

Note. ${ }^{* *} p<0.01$.

As a result of analysis, it is seen that there was a highly significant positive relationship between the fourth area of sub-competence (To make them gain the consciousness of understanding the democratic governance, and the people have responsibilities towards people, society, and humanity because of their innate and acquired rights) and the second area of sub-competence (To make students perceive the interaction of human, earth, and environment), and there were medium level positive meaningful relationships among the other sub-competencies.

Considering the fact that areas of sub-competences related to the teaching-learning process are mutually supportive, it was found that a positive relationship appeared among these sub-competences that directly relate to each other, which was regarded as an expected point.

In comparing the sub-competences beliefs related to the teaching-learning process according to gender of SSTCs, the results of the $t$-test for independent samples (see Table 2) were examined. It was observed that there were no statistically significant differences in dimensions of sub-competences 1,2 , and 3 according to the gender variable.

Table 2

SSTCs' Mean Scores of Sub-competence Areas According to Gender and T-Test Results

\begin{tabular}{|c|c|c|c|c|c|c|}
\hline Sub-competence & Gender & $N$ & $\bar{X}$ & $S$ & $t$ & $p$ \\
\hline \multirow[t]{2}{*}{ 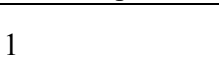 } & Female & 159 & 32.21 & 4.12 & \multirow{2}{*}{1.913} & \multirow{2}{*}{0.057} \\
\hline & Male & 201 & 31.29 & 4.95 & & \\
\hline \multirow{2}{*}{2} & Female & 159 & 28.55 & 3.52 & \multirow{2}{*}{1.514} & \multirow{2}{*}{0.131} \\
\hline & Male & 201 & 27.94 & 4.03 & & \\
\hline \multirow{2}{*}{3} & Female & 159 & 24.19 & 2.98 & \multirow{2}{*}{0.793} & \multirow{2}{*}{0.428} \\
\hline & Male & 201 & 23.93 & 3.26 & & \\
\hline \multirow{2}{*}{4} & Female & 159 & 50.22 & 5.68 & \multirow{2}{*}{2.804} & \multirow{2}{*}{$0.005^{*}$} \\
\hline & Male & 201 & 40.43 & 6.28 & & \\
\hline \multirow{2}{*}{5} & Female & 159 & 25.16 & 3.92 & \multirow{2}{*}{2.857} & \multirow{2}{*}{$0.005^{*}$} \\
\hline & Male & 201 & 23.94 & 4.12 & & \\
\hline \multirow{2}{*}{6} & Female & 159 & 27.98 & 4.93 & \multirow{2}{*}{2.319} & \multirow{2}{*}{$0.021^{*}$} \\
\hline & Male & 201 & 26.68 & 5.54 & & \\
\hline \multirow{2}{*}{ Total } & Female & 159 & 188.34 & 19.85 & \multirow{2}{*}{2.722} & \multirow{2}{*}{$0.007^{*}$} \\
\hline & Male & 201 & 182.23 & 22.13 & & \\
\hline
\end{tabular}

Note. ${ }^{*} p<0.05$.

It was observed that there was a statistically significant difference according to gender in the area of sub-competence $4\left(t_{(358)}=2.804 ; p<0.005\right)$. Looking at the arithmetic average scores, it was observed that the difference was in favor of female SSTCs. This finding could be interpreted as the efficacy beliefs of female SSTCs were more positive when compared with the male SSTCs relating to the sub-competence 4. 
It was observed that there was a statistically significant difference according to gender in the area of sub-competence 5 (To be able to get them comprehend the importance of the basic principles based on Atatürk's principles and reforms with the meaning of the Turkish revolution, its effects on the development of the society's political, social, cultural, and economic areas) $\left(t_{(358)}=2.857 ; p<0.005\right)$. Looking at the arithmetic average scores, it was observed that the difference was in favor of female SSTCs. This finding could be interpreted as efficacy beliefs of female SSTCs were more positive when compared with the male SSTCs relating to the sub-competence 5 .

It was observed that there was a statistically significant difference according to the gender variable in the area of sub-competence $6\left(t_{(358)}=2.319 ; p<0.021\right)$. Looking at the arithmetic average scores, it was observed that the difference was in favor of female SSTCs. This finding could be interpreted as efficacy beliefs of female SSTCs were more positive when compared with the male SSTCs relating to the sub-competence 6 .

When sub-competence areas were examined in conjunction with all dimensions, it was observed that there was a statistically significant difference according to their gender in the sub-competences beliefs related to the teaching-learning process of SSTCs $\left(t_{(358)}=2.722 ; p<0.007\right)$. Considering the arithmetic average scores, it was observed that the difference was in favor of female SSTCs. This finding could be interpreted as sub-competences beliefs related to the teaching-learning process of female SSTCs were more positive than male SSTCs.

In comparing the sub-competences beliefs related to the teaching-learning process according to education type of the SSTCs, the results of the $t$-test for independent samples (see Table 3) were examined.

Table 3

SSTCs' Mean Scores of Sub-competence Areas According to Education Type and T-Test Results

\begin{tabular}{|c|c|c|c|c|c|c|}
\hline Sub-competence & Education & $N$ & $\overline{\bar{X}}$ & $S$ & $t$ & $p$ \\
\hline \multirow{2}{*}{1} & Daytime & 199 & 31.23 & 4.49 & \multirow{2}{*}{2.163} & \multirow{2}{*}{$0.031^{*}$} \\
\hline & Evening & 161 & 32.28 & 4.72 & & \\
\hline \multirow{2}{*}{2} & Daytime & 199 & 27.84 & 3.54 & \multirow{2}{*}{2.005} & \multirow{2}{*}{$0.046^{*}$} \\
\hline & Evening & 161 & 28.65 & 4.11 & & \\
\hline \multirow{2}{*}{3} & Daytime & 199 & 23.81 & 2.90 & \multirow{2}{*}{1.535} & \multirow{2}{*}{0.126} \\
\hline & Evening & 161 & 24.32 & 3.40 & & \\
\hline \multirow{2}{*}{4} & Daytime & 199 & 48.67 & 5.56 & \multirow{2}{*}{1.920} & \multirow{2}{*}{0.056} \\
\hline & Evening & 161 & 49.90 & 6.62 & & \\
\hline \multirow{2}{*}{5} & Daytime & 199 & 24.15 & 3.93 & \multirow{2}{*}{1.740} & \multirow{2}{*}{0.083} \\
\hline & Evening & 161 & 24.90 & 4.22 & & \\
\hline \multirow{2}{*}{6} & Daytime & 199 & 27.16 & 4.85 & \multirow{2}{*}{0.370} & \multirow{2}{*}{0.711} \\
\hline & Evening & 161 & 27.37 & 4.22 & & \\
\hline \multirow{2}{*}{ Total } & Daytime & 199 & 182.88 & 18.99 & \multirow{2}{*}{1.982} & \multirow{2}{*}{$0.048^{\prime}$} \\
\hline & Evening & 161 & 187.45 & 23.74 & & \\
\hline
\end{tabular}

Note. ${ }^{*} p<0.05$.

It was observed that there was a statistically significant difference according to the education type in the area of sub-competence $1\left(t_{(358)}=2.163 ; p<0.031\right)$. Looking at the arithmetic average scores, it was observed that the difference was in favor of SSTCs studying in evening education. This finding could be interpreted as efficacy beliefs of SSTCs studying in evening education were more positive than SSTCs studying in daytime education relating to the sub-competence 1 .

It was observed that there was a statistically significant difference according to the education type in the area of sub-competence $2\left(t_{(358)}=2.005 ; p<0.046\right)$. Looking at the arithmetic average scores, it was observed 
that the difference was in favor of SSTCs studying in evening education. This finding could be interpreted as efficacy beliefs of SSTCs studying in evening education were more positive than SSTCs studying in daytime education relating to the sub-competence 2 .

It was observed that there were no statistically significant differences in dimensions of sub-competences 3 , 4,5 , and 6 according to the education type variable.

When sub-competence areas were examined in conjunction with all dimensions, it was observed that there was a statistically significant difference according to their education type in the sub-competences beliefs related to the teaching-learning process of SSTCs $\left(t_{(302.95)}=1.982 ; p<0.048\right)$. Looking at the arithmetic average scores, it was observed that the difference was in favor of SSTCs studying in evening education. This finding could be interpreted as sub-competences beliefs related to the teaching-learning process of SSTCs studying in evening education were more positive than the SSTCs studying in daytime education.

\section{How Are the Expectations of SSTCs Related to Their Deficiencies About the Teaching-Learning Process Towards the Teacher Training Program at the Undergraduate Level?}

At the end of the inventory about the teaching-learning process, the study group was asked to write their expectations related to the teacher training program that they received. One hundred participants from the study group were randomly selected for content analysis.

In Table 4, it is shown that modifications are expected by SSTCs towards to the teacher training program in social studies section. According to the results of the content analysis, responses are concentrated on the first four items as shown above $(66 \%)$. The SSTCs primarily complained about the presence of the theoretical course, in contrast, they asked for more practice-oriented courses. Secondly, they found themselves inadequate in the field of special education and want this course to be more practical. Thirdly, they want the educational science courses, such as child psychology, developmental psychology, special education, instructional methods and techniques, counseling, and measurement and evaluation must be given weight.

Table 4

SSTCs' Expectations About the Teacher Training Program They Received $(N=100)$

\begin{tabular}{|c|c|c|}
\hline Theme & Code & $F(\%)$ \\
\hline \multirow{16}{*}{$\begin{array}{l}\text { Related to } \\
\text { the program }\end{array}$} & In the program, I want that practical courses should be given weight rather than theoretical courses. & 20 \\
\hline & $\begin{array}{l}\text { I would like that the special education course should be given weight and I want this course to be more } \\
\text { application-oriented. }\end{array}$ & 19 \\
\hline & $\begin{array}{l}\text { The educational science courses should be given weight, such as child psychology, developmental psychology, } \\
\text { special education, instructional methods and techniques, counseling, and measurement and evaluation. }\end{array}$ & 14 \\
\hline & I want the internship should be elevated to two or more years. & 13 \\
\hline & I want the lessons include recent history issues. & 7 \\
\hline & $\begin{array}{l}\text { I want the courses, such as elocution, problem-solving, communication and empathy, and student recognition } \\
\text { techniques be included in the program. }\end{array}$ & 6 \\
\hline & I want the communication courses more. & 5 \\
\hline & It should be explained how we can express ourselves and how we can understand the others in college. & 4 \\
\hline & An opportunity should be provided to increase the number of elective courses and give a variety for them. & 3 \\
\hline & I think the core courses, such as history and geography, should be given weight. & 3 \\
\hline & I would like to increase the amount of courses, such as citizenship, Turkish culture, law, and communication. & 1 \\
\hline & I want to increase counseling services for students in college. & 1 \\
\hline & I would like to increase the amount of vocational knowledge courses as well as field courses. & 1 \\
\hline & I want the new courses that include new technologies should be given place. & 1 \\
\hline & I think the international relations course should be given. & 1 \\
\hline & I want the educational science course should be given specific to the field of social stu & 1 \\
\hline
\end{tabular}


In the fourth line, some of the SSTCs wanted the internship must be elevated to two or more years. Apart from these, they wanted some issues such as recent history, elocution, problem-solving, communication, empathy, and student recognition techniques must be included in courses (18\%). Additionally, the SSTCs stated their expectations for some other matters as shown above (16\%).

\section{Discussion and Conclusion}

Many researchers have examined the impact of self-efficacy on the profession of teaching from different perspectives. It was observed that the studies regarding teacher efficacy have increased in recent years. The reason of addressing the teacher candidates' efficacy beliefs by many researchers is a direct effect to the teaching-learning process related to the profession efficacy beliefs. Teachers' efficacy beliefs affect both student achievement and their vocational success (Bandura, 1993; Guskey, 1988; Stein \& Wang, 1988; Ross, 1992; Midgley, Feldlaufer, \& Eccles, 1989). Teachers' self-efficacy beliefs contribute significantly to students' academic achievement and job satisfaction (Caprara, Barbaranelli, Steca, \& Malone, 2006). Dönmez and Avc1 (2013) showed that SSTCs seemed to trust themselves about being good models to their students, and believe themselves sufficient about how they used strategies that could lead to positive change in the students' character. Results of this study demonstrated that the SSTCs had an upper-average efficacy beliefs regarding the teaching-learning process in all sub-competences (see Table 1). This result indicates that the SSTCs think that they can perform their profession in a good way. In other words, the teacher candidates participating in the study see themselves adequate in the teaching-learning process, and it shows that they trust in their knowledge and skills. However, the gathered findings from the qualitative dimension support the opinion that the teacher training program they received is not sufficient for the SSTCs.

In this study, a statistically significant difference was found according to gender. There was a statistically significant difference according to gender in the area of sub-competences 4, 5, and 6 and in summed score in favor of female SSTCs (see Table 2). On the contrary, some studies showed that there were no significant differences between gender and self-efficacy (Akbaş \& Çelikkaleli, 2006; Çakıroğlu, Çakıroğlu, \& Bone, 2005; Şahin-Taşkın \& Hacıömeroğlu, 2010). Demirtaş, Cömert, and Özer (2011) concluded that pre-service teachers had a positive attitude towards the profession and male candidates perceived themselves more competent than female candidates. However, efficacy beliefs related to the teaching-learning process of female SSTCs were more positive to male SSTCs in this study. The reason for this may be that earlier studies were conducted in different branches. In social studies branch, teacher candidates find themselves more adequate. Demirtaş et al. (2011) revealed that self-efficacy beliefs of pre-service teachers did not differentiate according to the variable of education type. On the contrary, it was observed in this study that efficacy beliefs of SSTCs studying in evening education were more positive than SSTCs studying in daytime education. The higher belief levels on self-efficacy of female SSTCs and SSTCs in evening education can be explained as female teacher candidates are diligent in comparison to male and the evening education students are zealous compared with the daytime education students, in general.

Teacher practice course plays an important role in the development of teacher candidates' efficacy beliefs. Hoy (2000) also emphasized the importance of vicarious experiences on teacher efficacy; it was consistent with qualitative findings of the study. The SSTCs asked for more practice-oriented courses and wanted that internship must be elevated to two or more years. The reason for this may be that the teaching profession is implementation-oriented by its very nature. 
According to the qualitative findings, the SSTCs felt inadequate on special education at most. This finding was parallel to the previous research results. Some studies showed that teachers' self-efficacy beliefs were affected by their students' disability. There was a relationship between the increase in academic achievement of students with learning difficulties and the increase of teachers' self-efficacy beliefs; teachers could develop a sense of inadequacy when they felt that they could not solve the problems of students' disability (Ashton \& Webb, 1986; Shachar \& Shmuelevitz, 1997; Dembo \& Gibson, 1985).

Teacher candidates' efficacy beliefs towards their profession have a great influence on their teaching abilities. Before becoming experienced in the profession, providing effective learning experiences to their students is usually effective. In addition to other branches of teaching, social studies teaching may be the most often associated field with individual psychology due to its structure. SSTCs' higher efficacy beliefs associated with their profession on the teaching-learning process may mean that they will perform their profession better. Even if the SSTCs had high efficacy beliefs, they would like to make several modifications towards the teacher training program they received. When selecting courses for social studies education sections, the qualitative results of this research will be useful in particular.

\section{References}

Ashton, P., \& Webb, R. (1986). Making a difference: Teacher's senseof efficacy and student achievement. White Plains, N.Y.: Longman, Inc..

Akbaş, A., \& Çelikkaleli, Ö. (2006). The investigation of the preservice elementary teachers' science instruction self-efficacy beliefs according to their gender, type of education, and universities. Mersin University Journal of the Faculty of Education, 2(1), 98-110.

Bandura, A. (1989a). Human agency in social cognitive theory. American Psychologist, 44, 1175-1184.

Bandura, A. (1989b). Social cognitive theory. In R. Vasta (Ed.), Annals of child development (Vol. 6. Six theories of child development). Greenwich, C.T.: JAI Press.

Bandura, A. (1993). Perceived self-efficacy in cognitive development and functioning. Educational Psychologist, 28(2), 117-148.

Bandura, A. (1995). Self-efficacy in changing societies. New York, N.Y.: Cambridge University.

Caprara, G. V., Barbaranelli, C., Steca, P., \& Malone, P. S. (2006). Teachers' self-efficacy beliefs as determinants of job satisfaction and students' academic achievement: A study at the school level. Journal of School Psychology, 44, 473-490.

Çakıroğlu, J., Çakıroğlu, E., \& Bone, W. J. (2005). Pre-service teacher self-efficacy beliefs regarding science teaching: A comparison of pre-service teachers in Turkey and the USA. Science Educator, 14(1), 31-40.

Darling-Hammond, L. (2002). Solving the dilemmas of teacher supply, demand, and standards: How we can ensure a competent, caring, and qualified teacher for every child (National Commission on Teaching and America's Future Research Report).

Dembo, M. H., \& Gibson, S. (1985). Teacher's sense of efficacy: An important factor in school improvement. Elementary School Journal, 86, 173-184.

Demircioğlu, İ. H. (2006). Social studies teacher candidates' views about social sciences. Bilig, 36, 113-124.

Demirtaş, H., Cömert, M., \& Özer, N. (2011). Pre-service teachers' self-efficacy beliefs and attitudes towards profession. Education and Science, 36(159), 96-111.

Dönmez, C., \& Avc1, E. (2013). The efficacy beliefs of social studies trainees teacher about character education. The International Journal of Learning, 18(12), 301-312.

Elliott, E. M., Isaacs M. L., \& Chugani C. D. (2010). Promoting self-efficacy in early career teachers: A principal's guide for differentiated mentoring and supervision. Florida Journal of Educational Administration \& Policy, 4(1), 131-146.

Goddard, R. D., Hoy, W. K., \& Hoy, A. W. (2000). Collective teacher efficacy: Its meaning, measure, and impact on student achievement. American Educational Research Journal, 37(2), 479-507.

Guskey, T. R. (1988). Teacher efficacy, self-concept, and attitudes toward the implementation of instructional innovation. Teaching and Teacher Education, 4(1), 63-69.

Guyton, E., \& Farokhi, E. (1987). Relationships among academic performance, basic skills, subject matter knowledge, and teaching skills of teacher education graduates. Journal of Teacher Education, 38(5), 37-42. 
Hawk, P. P., Coble, C. R., \& Swanson, M. (1985). Certification: It does matter. Journal of Teacher Education, 36(3), 13-15.

Hoy, A. W. (2000). Changes in teacher efficacy during the early years of teaching. Paper presented at The Annual Meeting of the American Educational Research Association, New Orleans.

Hoy, A. W., Hoy, W. K., \& Davis, H. A. (2009). Teachers' self-efficacy beliefs. In K. R. Wentzel, \& A. Wigfield (Eds.), Handbook of motivation at school (pp. 627-653). New York and London: Routledge Taylor \& Francis Group.

McMillan, H., \& Schumacher, S. J. (2006). Research in education evidence-based inquiry. Boston, M.A.: Allyn and Bacon Inc..

Midgley, C., Feldlaufer, H., \& Eccles, J. (1989). Change in teacher efficacy and student self- and task- related beliefs in mathematics during the transition to junior high school. Journal of Educational Psychology, 81, 247-258.

Ross, J. A. (1992). Teacher efficacy and the effects of coaching on student achievement. Canadian Journal of Education, 17(1), 51-65.

Şahin-Taşkın, Ç., \& Hacıömeroğlu, G. (2010). Examining elementary preservice teachers' self-efficacy beliefs: Combination of quantitative and qualitative methods. Inonu University Journal of the Faculty of Education, 11(1), 21-40.

Saklofske, D., Michaluk, B., \& Randhawa, B. (1988). Teachers' efficacy and teaching behaviors. Psychological Report, 63, 407-414.

Schunk, D. H., \& Pajares, F. (2009). Self-efficacy theory. In K. R. Wentzel, \& A. Wigfield (Eds.), Handbook of motivation at school (pp. 35-53). New York and London: Routledge Taylor \& Francis Group.

Shachar, H., \& Shmuelevitz, H. (1997). Implementing cooperative learning: Teacher collaboration and teachers' sense of efficacy in heterogeneousjunior high schools. Contemporary Educational Psychology, 22, 53-72.

Stein, M. K., \& Wang, M. C. (1988). Teacher development and school improvement: The process of teacher change. Teaching and Teacher Education, 4, 171-187.

Tschannen-Moran, M., \& Hoy, A. W. (2001). Teacher efficacy: Capturing an elusive construct. Teaching and Teacher Education, $17,783-805$.

Zulkosky, K. (2009). Self-efficacy: A concept analysis. Nursing Forum, 44(2). 